\title{
Comparison of Hardness and Wear Behaviour of Boronized and Carburized AISI 8620 Steels
}

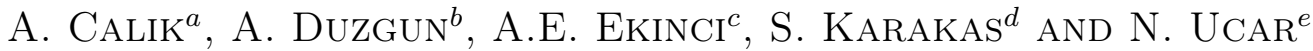 \\ ${ }^{a}$ Department of Mechanical Education, Technical Education Faculty \\ Suleyman Demirel University, Isparta, Turkey \\ ${ }^{b}$ Engineering Faculty, Civil Engineering Department, Ataturk University, Erzurum, Turkey \\ ${ }^{c}$ Physics Department, Art and Science Faculty, Erzincan University, Erzincan, Turkey \\ ${ }^{d}$ Department of Mechatronics Education, Technical Education Faculty \\ Suleyman Demirel University, Isparta, Turkey \\ ${ }^{e}$ Physics Department, Art and Science Faculty, Suleyman Demirel University, Isparta, Turkey
}

(Received July 10, 2009)

\begin{abstract}
In this study, the hardness and wear behaviour of carburized and boronized AISI 8620 steels have been studied. The boronizing treatment increased the hardness of AISI 8620 steels from $395 \mathrm{HV}_{0.1}$ to a maximal $1610 \mathrm{HV}_{0.1}$ compared to the carburized steels and also significantly improved its wear behaviour. From obtained results, it can be concluded that boronizing is very effective surface hardening method for improving the wear properties of AISI 8620 steels.
\end{abstract}

PACS numbers: 62.20.--x, 62.20.M-, 62.20.Qp, 68.35.Fx

\section{Introduction}

Owing to their high wear resistance, steels are widely used as wear-resistant bulk and hard facing materials in a range of industrial applications as valves, shafts, gears, etc. [1-4]. However, most engineering components are subject to wear, and considerable economic losses occur due to wear in the engineering components of machine and equipment during service. The importance of surface treatments based on both classical and modern technologies has therefore increased [5]. Carburizing, also known as carburization, is a heat treatment process in which the surface composition of the low carbon steel changes by diffusion of carbon and results in a hard outer shell (case) with good wear resistance [6]. On the other hand, boronizing is a thermochemical surface hardening treatment similar to carburization, which enriches the material surface with boron by diffusion of boron atoms into the surface of the material at high temperatures $[7,8]$. In Refs. [5, 9], it has been shown that using surface treatments on engineering materials increases the wear resistance, decreases the friction coefficient, and improves corrosion resistance. Corresponding to this, Tabur et al. [9] showed that the boronized steels exhibit surface hardness over $2000 \mathrm{HV}$ and provide improved abrasive and adhesive wear resistance. Comparison of other surface hardening treatments such as carburizing and nitriding with boronizing for steels used in the industry shows that the boronized steels have superior tribological characteristics $[9,10]$. In addition, although the wear resistance of the borocarburized layer has been determined to be higher in comparison with that for borided or carburized layers, the microhardness gradient in borocarburized layer has been found to be reduced in comparison with the only borided layer [11].

Low-carbon or low-alloy steels (such as AISI 8620 steels) are often used for carburizing applications. The chemical compositions of these steels are not unlike those of dual-phase steels, in that the latter contain low percentages of $\mathrm{C}(<0.3 \%), \mathrm{Si}, \mathrm{Mn}, \mathrm{Cr}$ and other alloying elements [12]. AISI 8620 steels are carburizing steels used in moderate section sizes and are among the most widely used case-hardening steels. Wear of industrial machine parts is important as it may, in some cases, cause rapid failure in the system [9]. In this study we focus on the comparison of hardness and wear behaviour of boronized and carburized AISI 8620 steels.

\section{Experimental method}

AISI 8620 steels are commercially produced as gear materials with the compositions shown in Table I. The test pieces used in microhardness tests were cut to $2 \mathrm{~mm}$ diameter and $30 \mathrm{~mm}$ length and annealed at $900 \mathrm{~K}$ for $10 \mathrm{~h}$ to remove potential residual stresses before machining the specimens. The samples were treated by two thermochemical treatment methods: boronizing and carburizing. The boronizing of the steels was achieved in a solid medium using the powder pack method. In this method, a commercial Ekabor-II boron source and an 
TABLE I

Chemical composition (wt.\%) of the gear material (AISI 8620).

\begin{tabular}{c|c|c|c|c|c|c|c}
\hline \hline $\mathrm{C}$ & $\mathrm{Mn}$ & $\mathrm{Cr}$ & $\mathrm{Mo}$ & $\mathrm{Si}$ & $\mathrm{S}$ & $\mathrm{P}$ & $\mathrm{Fe}$ \\
\hline 0.218 & 0.792 & 0.770 & 0.160 & 0.033 & 0.027 & 0.019 & Bal.
\end{tabular}

activator, ferrosilicon ( $\mathrm{Fe}-\mathrm{Si}$ ) were thoroughly mixed to form the boronizing medium. The test samples were packed with the boronizing medium and heated in an electrical resistance furnace for $4 \mathrm{~h}$ at $1210 \mathrm{~K}$ under the atmospheric pressure. The carburization treatment was carried out under the same temperature and for the same duration, by using graphite as the carburizing medium. During this process, carbon was diffused into the material, and thus, a carbon-diffused zone was formed at the surface region. After the treatments, the boronized and the carburized steels were removed from the furnace, cooled in air, sectioned from one side, fine ground with 1200-grit SiC abrasive papers, and polished using $3 \mu \mathrm{m}$ alumina paste. The surfaces of the polished samples were etched with $4 \%$ Nital. The thicknesses of diffusion layers of boronized and carburized AISI 8620 steels were observed by optical microscopy and hardness tests, results of which are given in Fig. 1 and Table II, respectively. The presence of phases on the surface of the carburized and the boronized steels were analyzed using an X-ray diffractometer (Rigaku D-MAX 2200) with a $\mathrm{Cu} K_{\alpha}$ radiation of $0.15418 \mathrm{~nm}$ wavelength and energy dispersive spectroscopy (EDS) analysis (Fig. 2a and b). The hardness of the carburized and the boronized AISI 8620 steels was measured by using a Vickers microhardness tester with a load of $100 \mathrm{~g}$. The results are summarized in Table II. Wear tests of the gear materials were also performed, with a $90 \mathrm{~N}$ weight. The weight losses of the borided, carburized, and untreated AISI 8620 steels were determined as a function of time (Fig. 3).

TABLE II

The thickness and hardness values of the steels tested.

\begin{tabular}{c|c|c|c|c|c}
\hline \hline $\begin{array}{c}\text { Surface } \\
\text { diffusion } \\
\text { method }\end{array}$ & $\begin{array}{c}\text { Carburizing } \\
\text { and boronizing } \\
\text { layer thickness } \\
{[\mu \mathrm{m}]}\end{array}$ & $\begin{array}{c}\text { The thickness } \\
\text { of transition } \\
\text { region } \\
{[\mu \mathrm{m}]}\end{array}$ & $\begin{array}{c}\text { Surface } \\
\text { hardness } \\
(\text { HV0.1) }\end{array}$ & $\begin{array}{c}\text { The hardness } \\
\text { of the transition } \\
\text { zone } \\
(\text { HV0.1) }\end{array}$ & $\begin{array}{c}\text { Substructure } \\
\text { hardness } \\
(\text { HV0.1) }\end{array}$ \\
\hline $\begin{array}{c}\text { carburizing } \\
\text { boronizing }\end{array}$ & $5-6$ & $55-65$ & $870-885$ & $540-580$ & $370-405$ \\
$155-65$ & 165 & $1578-1610$ & $380-410$ & $370-395$
\end{tabular}

\section{Results and discussion}

Thermochemical heat treatments such as carbonitriding, carburizing and boronizing are widely used to improve surface properties of ferrous material for increasing their wear, corrosion and fatigue performance [3]. Depending on the boronizing/carburizing source, time, temperature, and chemical composition of substrate, the boride and/or carbide, and niobium carbide layer forms on the substrate and its depth changes with these parameters [13]. In the present study, it is observed that the boride layer of AISI 8620 steels has a denticulate morphology (Fig. 1a). In the carburized AISI 8620 steels, the surface region can be clearly distinguished from the core material, which is the case formed by carburizing (Fig. 1b). As can be seen from these figures, the thickness of the boride layer is in the range of $55 \mu \mathrm{m}$ to $65 \mu \mathrm{m}$ whereas the thickness of the carburized case is in the range of $5 \mu \mathrm{m}$ to $6 \mu \mathrm{m}$ (Fig. 1 and Table II). It is evident that the boride layer thicknesses of boronized AISI 8620 steels are more noticeable than those of the carburized AISI 8620 steels. This difference is mainly due to the different diffusion mechanisms which involve the ac- tivation energies and atomic radii of boron and carbon. The $\mathrm{Fe}_{2} \mathrm{~B}$ phase in the boride layer of AISI 8620 steels investigated by optical microscopy was distinguished by the changes in contrast (Fig. 1) and microhardness values (Table II). Also, the diffraction pattern of the boride layer in Fig. 2a shows the presence of $\alpha$-SiC, which was most likely introduced into the layer by abrasive pickup during specimen preparation (which involved the usage of $\mathrm{SiC}$ abrasive papers). The diffusion layers of the carburized AISI 8620 steels have different $\mathrm{C}$ concentration which decreases from the surface to interior. In this region, $\mathrm{Fe}_{3} \mathrm{C}$ phase was rarely seen in these steels where their presence has been detected by X-ray diffraction (XRD) and EDS analysis (Fig. 2).

In addition to diffusion layer, the boronized and carburized AISI 8620 steels have transition zone and matrix (that is not affected by boron and carbon). More importantly, hardness profile measurement revealed that the hardness in the layer decreases gradually from the surface towards the layer-core interface (Table II). It can be seen from Table II that the hardness of the diffusion layers of boronized and carburized AISI 8620 steels is much 

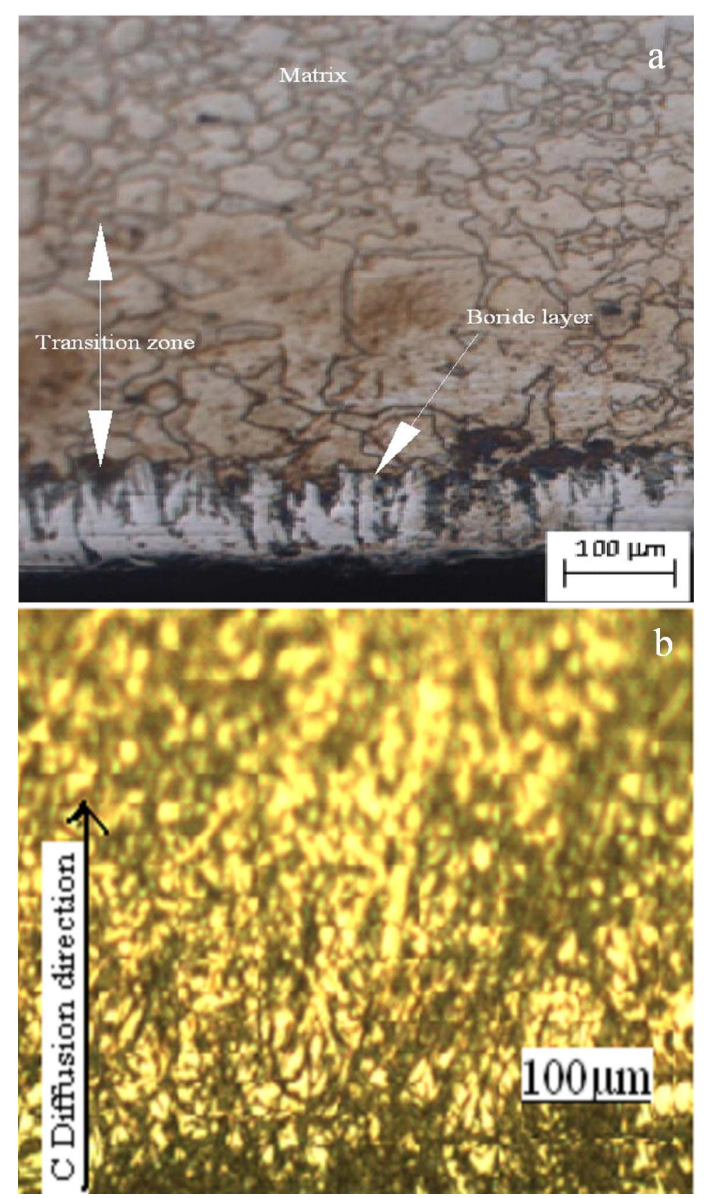

Fig. 1. Optical micrograph of cross-section of AISI 8620 steels: (a) boronized, (b) carburized.

higher than that of the matrix. These are consequences of the presence of the hard phase such as $\mathrm{Fe}_{2} \mathrm{~B}, \alpha-\mathrm{SiC}$ and $\mathrm{Fe}_{3} \mathrm{C}$ in the diffusion layers. These results are in good agreement with the results obtained by Ucisik and Bindal [14] and Sun [15].

Now let us consider the relation between hardness and wear properties of the AISI 8620 steels. It is well known that the amount of wear in any component depends upon a number of factors such as applied load, testing machine characteristics, sliding speed, sliding distance, environment and material properties [16]. In the present study, a special wear testing machine with a load of $90 \mathrm{~N}$ was used to measure wear behavior of the AISI 8620 steels. Under the same test condition, the weight loss of the carburized and boronized AISI 8620 steels as a function of test time was measured and is given in Fig. 3. This figure shows the weight loss of the AISI 8620 steels found through the wear tests performed after surface hardening and also untreated steels. As can be seen from this figure, the weight loss of all three AISI 8620 steels increases with testing time. The weight loss of the carburized AISI 8620 steel is lower than that of untreated AISI 8620 steel but higher than that of the boronized AISI 8620 steel. The

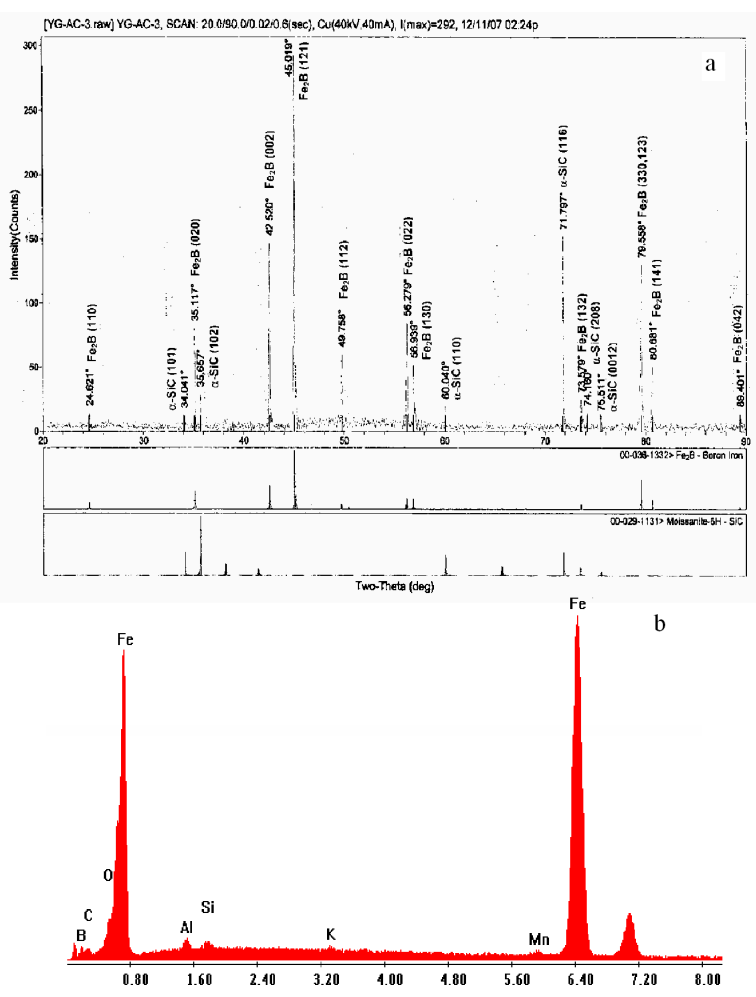

Fig. 2. XRD analysis of boronized AISI 8620 steels and EDS spectrum analysis of carburized AISI 8620 steels.

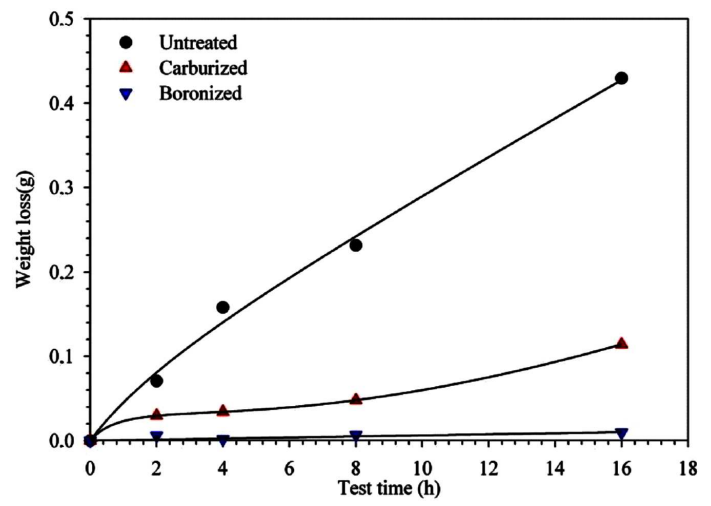

Fig. 3. Weight loss vs. test time curves measured for untreated, boronized and carburized AISI 8620 steels.

carburized steel also shows a distinct running-in stage in the first two hours of the test. There is apparently a linear relationship between the wear behavior and hardness of the steels. It is therefore claimed that the boronized AISI 8620 steels show improved wear performance because of their superior hardness properties. The thickness of diffusion layer also contributes to the high wear properties of boronized AISI 8620 steel. In the present study, the diffusion layer of carburized AISI 8620 steels was measured to be in the range of $5-6 \mu \mathrm{m}$. It is therefore proposed that the carburized steel having such a thin hardened layer might not have had sufficient thickness to 
bear the long-duration wear test. On the other hand, the superior wear performance of boronized AISI 8620 steels can be attributed to the hard boride layer consisting of the $\mathrm{Fe}_{2} \mathrm{~B}$ and $\alpha$-SiC phases. These results indicate that carburizing is not as effective as boronizing in improving the wear behavior of AISI 8620 steels. In other words, when compared to carburized AISI 8620 steels, boronized AISI 8620 steels have a better wear characteristics because of the greater surface hardening effect and relatively thick diffusion layer.

\section{Conclusions}

The conclusions arising from the present work are as follows:

1. Three distinct regions were identified on the surface of steels: (i) the diffusion layer, (ii) the transition zone, and (iii) the matrix that is not affected by boron and carbon. The prominent phases formed in the surface layer of boronized and carburized AISI 8620 steels were $\mathrm{Fe}_{2} \mathrm{~B}, \alpha$-SiC, and rarely $\mathrm{Fe}_{3} \mathrm{C}$, respectively, which were revealed by XRD and EDS analyse.

2. The diffusion layer formed on the surface of boronized AISI 8620 steel has a denticular morphology, whereas the diffusion layer of the carburized steel is comparatively smooth and flat. The thickness of diffusion layer was measured as 5-6 $\mu \mathrm{m}$ and $55-65 \mu \mathrm{m}$ for the carburized and the boronized AISI 8620 steels, respectively.

3. The hardness of diffusion layer was found to be much higher than that of matrix for both carburized and boronized steels. The weight loss increases with the increasing test time. There is a linear relationship between hardness and wear characteristics of AISI 8620 steels.

\section{References}

[1] B.X. Yan, X.M. Zhang, J.W. Xu, Z.G. Wu, Q.M. Song, Mater. Chem. Phys. 71, 107 (2001).

[2] C.H. Xu, J.K. Xi, W. Gao, J. Mater. Process Technol. 65, 94 (1997)

[3] B. Selcuk, R. Ipek, M.B. Karamis, J. Mater. Process Technol. 141, 189 (2003).

[4] B.S. Mann, Wear 208, 125 (1997).

[5] E. Atik, U. Yunker, C. Meric, Tribo Int. 36, 155 (2003).

[6] M. Tarakci, K. Korkmaz, Y. Gencer, M. Usta, Surf. Coat. Technol. 199, 205 (2005).

[7] A.K. Sinha, Heat Treating 4, 437 (1991).

[8] S.Y. Lee, G.S. Kim, B.-S. Kim, Surf. Coat. Technol. 177, 178 (2004).

[9] M. Tabur, M. Izciler, F. Gul, I. Karacan, Wear 266, 1106 (2009).

[10] T. Makıshı, K. Nakata, Metall. Mater. Trans. A 35, 227 (2004).

[11] A. Pertek, M. Kulka, Surf. Coat. Technol. 173, 309 (2003).

[12] M. Erdogan, S. Tekeli, Mater. Character. 49, 445 (2003).

[13] I. Uslu, H. Comert, M. Ipek, F.G. Celebi, O. Ozdemir, C. Bindal, Mater. Design 28, 1819 (2007).

[14] A.H. Ucisik, C. Bindal, Surf. Coat. Technol. 94, 561 (1997).

[15] Y. Sun, Mater. Design 30, 1377 (2009).

[16] A. Bensely, A. Prabhakaran, D. Mohan Lal, G. Nagarajan, Cryogenics 45, 747 (2006). 